\title{
METANARASI DALAM NOVEL METAMORFOSA KARYA FRANZ
} KAFKA

\author{
Wisma Kurniawati \\ Universitas Negeri Surabaya \\ Mahasiswa S-3 Program Studi Bahasa dan Sastra Universitas Negeri Surabaya \\ Wismakurniawati@yahoo.com
}

\begin{abstract}
ABSTRAK
Di era posmodernisme, sastra sering dianggap sebagai pemikiran. Salah satu karya sastra yang mencerminkan pemikiran adalah novel Metamorfosa karya Kafka. Melalui tokoh dan dunia yang ditampilkan, serta penceritaannya, Metamorfosa mampu merefleksikan pemikiran pengarang tentang masalah-masalah sosial, psikologi, dan politik masyarakat yang dipenuhi dengan dominasi dan kekuasaan. Kajian difokuskan pada dua pertanyaan. Pertama, metanarasi apa saja yang tergambar dalam novel Metamorfosa karya Kafka? Kedua, problematika sosial apa yang ditimbulkan dengan adanya metanarasi dalam novel Metamorfosa karya Kafka? Kajian dilakukan dengan menggunakan teori metanaratif Lyotard. Untuk menemukan dan mendeskripsikan metanarasi-metanarasi dalam Metamorfosa, digunakan konsep “differend" dan "fragmentasi" yang dikemukakan oleh Lyotard. Kajian menghasilkan temuan bahwa novel Metamorfosa merefleksikan pemikiran Kafka mengenai kesewenangwenangan yang disebabkan oleh metanarasi-metanarasi yang berkembang di masyarakat. Kesewenangwenangan tercermin dalam tiga fragmen, yakni kesewenangwenangan dalam dunia kerja, kesewenangwenangan dalam keluarga, dan kesewenangwenangan dalam lingkungan sosial. Melalui tiga fragmen tersebut dapat dilihat penyimpangan yang dilakukan pihak-pihak yang kuat, yang menimbulkan penderitaan, bahkan kehancuran yang berakhir dengan kematian bagi pihak yang lain.
\end{abstract}

Kata Kunci: metanarasi, metanaratif, differend, fragmentasi

ABSTRACT

In the era of postmodernism, literature is often regarded as thought. This was reflected on one of the literary works of Kafka, the Metamorphosis novel. Through the characters and the world displayed, as well as the story, Metamorphosis is able to reflect the author's thoughts on the social, psychological, and political issues of society populated with domination and power. This study focused on two questions. First, what metanaration is reflected in Kafka's Metamorphosis novel? Second, what social problems are caused by the metanarations in Kafka's Metamorphosis novel? The study was conducted using Lyotard's metanarative theory. To find and describe the metanarations in Metamorphosis, the concept of "differend" and "fragmentation" proposed by Lyotard were used. This study shows that the Metamorphosis novel reflects Kafka's thinking about the arbitrariness/domination caused by 
metanarations developing in the society. Arbitrariness is reflected in three fragments, arbitrariness in the world of work, arbitrariness in the family, and arbitrariness in the society. Through these three fragments, it is shown the deviations made by the powerful parties, which cause suffering, and even destruction that ends in death for the other side.

Keywords: metanaration, metanarative, differend, fragmentation

\section{PENDAHULUAN}

Sastra sering dianggap sebagai pemikiran (Wellek dan Warren, 1993:134). Pandangan yang menguatkan bahwa sastra tumpang tindih dengan pemikiran sangat menonjol di era posmodernisme. Menurut kaum posmodern, sastra - seperti juga karya pemikiran membicarakan objek yang sama, yaitu bagaimana masalah-masalah manusia diungkapkan, sehingga berfungsi untuk meningkatkan kualitas kehidupan (Ratna, 2013:150-151). Hadirnya posmodernisme pada tahun 1970-an membawa angin segar bagi tumbuhnya kajian yang mengaitkan antara sastra dan pemikiran. Sejak saat itu, aspek-aspek pemikiran dalam berbagai karya sastra, baik yang kontemporer maupun yang sudah ditulis di era sebelumnya, mulai dikaji secara lebih intensif.

Salah satu pengarang yang karya-karyanya dianggap sarat dengan pemikiran adalah Franz Kafka. Melalui karya-karyanya, Kafka mampu menggambarkan pemikirannya tentang masalahmasalah sosial, psikologi, dan politik masyarakat yang dipenuhi dengan dominasi dan kekuasaan. Meskipun masa aktif kepengarangan Kafka terhitung sejak tahun 1903 hingga akhir hayatnya di tahun 1924, karya-karyanya baru dikenal luas di dunia internasional setelah Perang Dunia kedua. Dia bahkan dinobatkan menjadi pengarang klasik posmodern, pertengahan tahun 80an, yaitu 60 tahun sesudah kematiannya (Bertl dan Müller, 1984:149150).

Novel Kafka yang paling diunggulkan adalah Die Verwandlung (Metamorfosa) (Beutin dkk., 1984:338). Melalui tokoh Gregor Samsa dan dunianya, Metamorfosa bercerita tentang berbagai konflik yang terjadi di masyarakat, sebab, dan akibat yang ditimbulkan. Misalnya, konflik buruh dengan pemilik modal, konflik anak dengan ayahnya, dan konflik individu dengan orangorang di sekelilingnya. Gregor yang dikelilingi oleh bermacammacam dominasi kekuasaan, dan Gregor yang tertindas oleh sistem kekuasaan di masyarakat yang diwakili oleh pemilik modal sebagai penguasa, orang-orang di sekitarnya hingga akhir hidupnya mengalami penderitaan hingga tewas mengenaskan. Dalam novel itu juga tergambar oposisi-oposisi antara pihak yang menindas dan ditindas, pihak yang berkuasa dan yang lemah.

Gambaran peristiwa dalam Metamorfosa merupakan sebagian masalah kemasyarakatan yang dibicakan oleh kaum posmodern, yaitu kesewenang-wenangan yang menimbulkan penderitaan manusia. Ratna (2013:155) menyebutkan bahwa posmodernisme menolak manusia yang berkuasa, dan membela manusia yang tertindas. Menurut kaum posmodern, kesewenang-wenangan 
semacam itu timbul karena dunia selama ini telah didominasi oleh pandangan-pandangan monosentrisme dan homologi yang dikembangkan oleh modernisme. Modernisme selalu berusaha memberikan intensitas yang tinggi pada uniformitas, homogenitas, dan totalitas. Dengan mencari definisi ontologis, mereka sekaligus memberikan penilaian-penilaian tentang baik-buruk, tinggi-rendah, umum-tidak umum sehingga muncul dikotomi "pihak yang satu baik, yang lain buruk", yang ujung-ujungnya melegitimasi adanya dominasi pihak-pihak tertentu.

Alih-alih menciptakan masyarakat madani seperti yang diinginkan, dominasi semacam itu justru menciptakan ketidakadilan di segala bidang kehidupan. Sebagai contoh, dalam bidang politik muncul rezim totaliter yang menindas masyarakat biasa, misalnya rezim totaliter Rusia yang menyengsarakan kaum buruh (proletar). Paham Rasisme, misalnya Hitler di Jerman yang menganggap bahwa hanya ras Aria yang boleh hidup sehingga pembunuhan massal terhadap ras lain adalah sesuatu yang wajar atau bahkan memang harus dilakukan. Dalam bidang sastra, karya sastra hanya boleh disandang oleh sastra kanon (belles letters), seperti karyakarya Marah Rusli, Sutan Takdir Alisyahbana, Khairil Anwar, atau Rendra, sedangkan sastra populer milik Mira W. atau Motinggo Busye dianggap sebagai karya trivial yang hanya cocok untuk mengisi waktu luang. Pengarang yang peka terhadap dunia paralogis seperti yang dipahami oleh kaum posmodernis, akan menciptakan dunia imajiner dengan ciri-ciri di atas karena dunia yang digambarkan sastra tersebut pada hakekatnya merupakan gambaran kebenaran yang dipahami oleh pengarang mengenai dunia dan kehidupan. Pihak-pihak yang dilegitimasi oleh modernisme sebagai yng universal, yang agung, yang baik tersebut di atas dalam posmodernisme dinamakan metanarasi atau grand narrative (narasi besar) (Lyotard, 1978).

Kelebihan Kafka lain yang diapresiasi oleh kaum posmodern adalah kemampuannya memunculkan metode narasi baru. Dalam karya-karyanya, Kafka menggunakan teknik penceritaan yang disebut dengan istilah die Krise des Erzählens (krisis penceritaan) (Bertl dan Müller, 1984:149-157). Dengan menggunakan metode penceritaan ini Kafka memadukan hal-hal yang bertentangan, misalnya rasionalitas dan irasionalitas dalam karyanya dan menempatkan ruang-ruang kosong tanpa penyelesaian yang menjadikan karyanya terlihat fragmentaris. Krisis penceritaan menjadikan karya-karya Kafka terbuka sehingga bersifat multiinterpretatif. Satu karya Kafka memungkinkan munculnya beragam makna. Berkat bentuk penceritaan seperti yang dibuat dalam karya Kafka, sifat multiinterpretatif menjadi salah satu tolok ukur keberhasilan bagi karya sastra jaman modern sehingga karya Kafka disebut sebagai "simbol sastra posmodern".

Dua hal tersebut di atas tampaknya merupakan bukti bahwa pengarang kelahiran Ceko ini dianggap mampu merepresentasikan dua pandangan utama posmodernisme sehingga layak untuk dikaji dengan teori posmodern. Seperti dinyatakan oleh Ratna (2013:156) 
posmodernisme dalam sastra mengubah pandangan mengenai ciriciri karya sastra. Sastra posmodern memiliki ciri-ciri sebagai berikut: (1) fiksi posmodern ditandai dengan teknik "campur aduk", yaitu dua dunia yang tidak saling berhubungan, misalnya antara aspek-aspek tradisional dengan modern, kejadian nyata dan khayal, (2) fiksi posmodern menolak makna tunggal, menerima makna sementara, dunia seolah-olah kosong, dan akan diisi terus-menerus oleh pembaca, (3) karya yang mendorong pembaca untuk selalu bertanya-tanya mengenai eksistensi realitas yang sesungguhnya (4) kalau manusia (tokoh dalam sastra) dalam modernisme hidup dalam sistem, dalam posmodernisme, manusia dimungkinkan hidup secara lebih bebas, sebagai destruktur, (5) posmodernisme menolak manusia berkuasa, sebaliknya membela manusia tertindas.

Berdasarkan uraian di atas, tulisan ini mengkaji pemikiran kritis terhadap metanarasi dalam novel Metamorfosa karya Kafka. Kajian akan difokuskan pada dua pertanyaan. Pertama, metanarasi apa saja yang tergambar dalam novel Metamorfosa karya Kafka? Kedua, problematika sosial apa yang ditimbulkan dengan adanya metanarasi dalam novel Metamorfosa karya Kafka? Teori yang digunakan adalah teori metanaratif yang dikembangkan oleh filsuf Perancis Jean Francois Lyotard.

Teori metanaratif merupakan salah satu teori yang termasuk dalam posmodernisme dengan tokoh pentingnya Jean Francois Lyotard. Posmodernisme merupakan gerakan kultural yang berkembang seiring dengan terbitnya buku Jean Francois Lyotard The Postmodern Condition (1979) dan The Differend: Phrases in Dispute (1984). Bangkitnya era posmodernisme pada abad ke-20 memunculkan teori-teori dan metode-metode baru dalam berbagai bidang kehidupan, antara lain ekonomi, sosial, politik, filsafat, kebudayaan, dan sastra. Salah satunya adalah teori metanaratif.

Lyotard tidak menyetujui tatanan konstruk-konstruk kebudayaan yang dilegitimasi oleh para modernis yang berciri uniformitas, homogenitas, dan totalisasi. Dia menyebut tatanantatanan tersebut sebagai narasi-narasi besar (metanarasi) sehingga teorinya disebut sebagai teori metanaratif (Hutcheon dalam Ratna, 2013:154). Lyotard dengan teori metanaratifnya berusaha mendekonstruksi atau membongkar metanarasi, sebaliknya dia memberikan intensitas pada perbedaan-perbedaan, relativitas, dan pluralitas menolak adanya pusat, kemutlakan.

Perkembangan teori metanaratif secara luas seiring dengan terbitnya buku The Postmodern Condition (1979) dan The Differend: Phrases in Dispute (1984). Inti dari dua buku ini adalah menolak legitimasi grand narrative (narasi besar/metanarasi). Sebagai contoh, Lyotard dalam The Postmodernism Conditions menolak universalitas ilmu pengetahuan dan dikotomi antara ilmu pengetahuan dengan narasi. Lyotard (1984:34) dengan tegas menolak legitimasi dan otoritas ilmu pengetahuan yang bersifat totaliter karena "Scientific knowledge does not represent the totality of knowledge; it has always axisted in addition to, ..., another kind of knowledge..." (ilmu pengetahuan tidak merepresentasikan 
totalitas pengetahuan; di sampingnya selalu ada pengetahuan lain). Menurut Lyotard (1984:30-34), ilmu pengetahuan sebagai pengetahuan yang diuniversalkan, merupakan salah satu bentuk metanarasi.

Menurut Lyotard (dalam Ratna, 2013:285) narasi menjadi buruk manakala dikaitkan dengan kepentingan politik atau agama sehingga mengorbankan kepentingan kelompok minoritas. Narasi besar buruk, sedangkan narasi kecil baik, demikian pernyataan Lyotard (dalam Ratna, 2013:285); Tidak ada penalaran universal, yang ada adalah bermacam-macam penalaran. Menguniversalkan pengetahuan berarti mendemoralisasi ilmuwan dan peneliti, oleh karena itu status ilmu pengetahuan harus dievaluasi. Pengesahanpengesahan baku hanya membawa masyarakat kehilangan kemampuan untuk melakukan perubahan. Misalnya, ilmu pengetahuan yang hanya mementingkan eksperimen tanpa menyadari dampak negatif terhadap masyarakat, doktrin-doktrin agama yang tidak mengatasi masalah masyarakat. Pengesahanpengesahan terhadap metanarasi justru memperburuk kondisi manusia.

Jadi, kajian kaum metanaratif ditujukan untuk mengkritisi narasi-narasi besar dalam wilayah peradaban manusia. Narasinarasi di balik pencapaian mitos jaman dibongkar atau bahkan ditumbangkan. Tatanan ideologis dalam berbagai bidang, gender, sosial budaya, seni, dan pengetahuan terus menerus didekonstruksi.

Ciri utama kajian metanaratif adalah mendekonstruksi narasinarasi besar. Prosedur yang digunakan dalam kajian-kajian metanaratif adalah "differend" (perbedaan) dan fragmentasi (Ratna:2013:287). Menurut Ratna, Differend yang dimaksud oleh Lyotard sama dengan "Difference" milik Derrida yang berarti keberagaman, kemajemukan, atau pluralitas. Pemaknaan terhadap teks masih bersangkut paut dengan unsur-unsur kebahasaan. Prosedur ini didasarkan pada alasan bahwa (1) Fakta adalah narasi; (2) Bentuk narasi - tidak seperti pengetahuan - cocok untuk berbagai macam permainan bahasa; (3) peran narator; peran narator dibedakan berdasarkan kategori usia, jenis kelamin, keluarga, atau kelompok profesional; (4) Bentuk narasi berefek pada irama dan waktu.

Sebuah teks (wacana) selalu dipenuhi dengan tanda-tanda; dan tanda-tanda itu memiliki wajah ganda (Derrida, 2005:78-88). Dalam mengungkap makna, pembaca harus selalu menaruh curiga terhadap tendensi-tendensi di balik teks. Oleh karena itu dalam mengungkap makna teks diperlukan pembacaan khusus yang disebut dengan pembacaan dekonstruktif. Kata dekonstruktif di sini diartikan sebagai “analisis”, artinya pembaca perlu mengurai struktur dan medan pemaknaan dalam teks, karena teks selalu berpeluang memberikan kejutan-kejutan pada pembaca (Derrida, 2005:78-79). Konsep itu oleh Lyotard diartikan sebagai manifestasi rezim frase dan genre wacana, dan setiap wacana memiliki aturan tersendiri, mewakili semesta masing-masing sehingga tidak dimungkinkan terjadinya semesta tunggal. Dalam analisis semacam 
itu, yang diperlukan oleh pembaca adalah kepekaan terhadap logika permainan bahasa.

Differend/Difference adalah strategi permainan yang ditawarkan oleh Lyotard dan Derrida (2005:86-88) dengan tujuan mengusik stabilitas teks dan mencairkan makna tunggal yang terbentuk melalui oposisi atau hierarki yang dibangun oleh teks. Dalam analisis semacam itu, yang diperlukan oleh pembaca adalah kepekaan terhadap logika permainan bahasa sehingga terungkap "the other" di balik teks. Teks menurut Derrida (2005:82) memiliki struktur telos yang terbuka; Tak ada satu kekuatan pun yang dapat menghentikan penafsiran-penafsiran baru. Makna yang diperoleh bukan makna final, karena semua makna selalu bersifat sementara.

Dalam penjelasan mengenai konsep differend, Derrida (2005:83-89) mengambil contoh penggunaan kata pharmakon dalam buku Plato Dissemination. Derrida mendemonstrasikan, bagaimana pengertian yang dikira tunggal, atau tampaknya memiliki makna atau referens yang jelas, ternyata sangat majemuk dan ambigu. Analisis terhadap kata pharmakon dalam buku tersebut diambil dari bagian-bagian yang berbeda. Dengan modus pembacaan dekonstruktif, Derrida membongkar pengertian tunggal dari kata tersebut.

Kata pharmakon dalam bahasa Yunani berarti obat-obatan atau racun. Namun, Berdasarkan hasil analisisnya terhadap esei pertama Plato, “Plato's Pharmacy”, Derrida menyimpulkan bahwa kata pharmakon digunakan untuk mendiskreditkan tulisan. Kata tersebut mengisyaratkan bahwa tulisan berbahaya bagi ingatan. Esei pertama Plato tersebut mengritik penemuan tulisan - sebagai sebuah teknik dan konsep. Bagi Plato, tulisan merupakan skandal terbesar dalam sejarah manusia dalam mencari kebenaran.

Kata pharmakon kedua diambil dari dialog antara Phaedrus dan Sokrates. Pada bagian ini, kata pharmakon menunjuk pada kekuatan penyembuh dari tulisan. Tulisan akan „akan membuat orang-orang Mesir lebih bijaksana dan akan memperbaiki ingatan mereka“. Namun, dalam paragraf yang sama juga dipakai untuk menyebuthal yang berbahaya: racun „membuat lupa jiwa-jiwa orang yang mempelajarinya“. Di sini tampak ambiguitas pharmakon.

Teks, kata Derrida (2005:86-88), mempunyai logikanya sendiri. Terdapat kekuatan-kekuaatan dalam teks yang tidak selamanya senada dengan penafsiran tunggal yang dibangun pengarang. Differend/Difference merupakan struktur dasar dari setiap teks. Dalam contoh di atas, Differend/Difference dalah pharmakon. Dalam praktik pembacaan semacam ini tak ada yang bisa dilakukan oleh pembaca selain ikut bermain-main dan mengambil jarak dengan setiap konsep yang hendak distabilkan. Pembaca memiliki peran penting untuk menghadirkan tendensitendensi tersembunyi dari teks.

Konsep kedua Lyotard adalah fragmentasi. Konsep ini berkaitan dengan penolakannya terhadap totalitas dan mengacu pada permainan bahasa, waktu, subjek manusia, dan masyarakat. 
Seni posmodern menurut Ratna (2013:288) menonjolkan fragmentasi, dengan cara menggabungkan sejumlah fragmen sehingga menimbulkan makna. Makna teks diperoleh dari fragmenfragmen yang disusun dengan teknik montase.

METODE

\section{PEMBAHASAN}

Penelitian ini didekati secara kualitatif karena bertujuan untuk mengungkap fenomena secara menyeluruh dan kontekstual tentang topik yang diteliti. Untuk menemukan metanarasi-metanarasi dalam novel Metamorfosa, digunakan metode deskriptif dengan konsep "differend" dan "fragmentasi” yang dikemukakan oleh Lyotard. Data diperoleh melalui teknik pustaka, dengan memanfaatkan sumber-sumber tertulis.

Pengumpulan data dilakukan dengan langkah-langkah berikut: Pertama, novel Metamorfosa dibaca berulang-ulang secara mendalam dan menyeluruh. Kedua, dilakukan pencatatan terhadap kata, frasa, kalimat yang menggambarkan kritik terhadap metanarasi dalam novel secara cermat dan teliti. Setelah data diperoleh, data diinterpretasi dengan konsep "differend" dan "fragmentasi" Lyotard. Pertama, fragmen-fragmen dalam novel Metamorfosa akan diuraikan secara deskriptif. Kedua, fragmenfragmen yang sudah ditemukan, diinterpretasi berdasarkan logika permainan bahasa dan tanda-tandanya akan diungkap "the other" (makna baru yang berbeda dari makna yang sudah ditemukan sebelumnya).

\section{Metanarasi dalam Novel Metamorfosa}

Untuk memahami dunia dalam Metamorfosa, pembaca harus mengikuti logika teks itu sendiri dan menjaga jarak terhadap teks. Logika itu dibangun dari kata-kata yang digunakan. Metanarasi dalam novel Metamorfosa bahkan sudah diperlihatkan pada judul yang digunakan. Kata „metamorfosa“ menjadi kata penting untuk dianalisis karena melalui kata tersebut bahwa dunia yang dipenuhi dominasi tidak bagus. Kata tersebut menjadi kunci bagi keseluruhan isi cerita yang disampaikan pengarang. Sebaliknya dunia plural membawa kebaikan pada semua pihak.

Dunia dalam Metamorfosa dibentuk dari fragmen-fragmen yang mirip dengan serpihan-serpihan mozaik berwarna-warni yang ditata secara acak dan sembarangan. Namun, melalui konflikkonflik yang dialami tokoh-tokoh dalam fragmen-fragmen itu, tampak gambaran dua metanarasi, yaitu kesewenangwenangan dalam dunia kerja yang dilakukan oleh majikan atau pemilik modal terhadap kaum buruh, kesewenangwenangan dalam keluarga yang dilakukan oleh ayah terhadap anak, dan kesewenangwenangan dalam lingkungan sosial yang dilakukan oleh manusia terhadap binatang. Fragmen-fragmen tersebut menggambarkan hubungan antagonis dan asimetris tentang peran dan kedudukan buruh dan majikan, ayah dan anak, serta manusia dan binatang, diuraikan dalam tiga subjudul, yaitu kesewenagwenangan dalam dunia kerja, kesewenangwenangan dalam keluarga, dan kesewenangwenangan dalam lingkungan sosial. 


\section{Kesewenangwenangan dalam Dunia Kerja}

Kesewenangwenangan dalam dunia kerja digambarkan melalui tokoh Prokura (Pemilik modal) dan tokoh Gregor Samsa. Gregor adalah pedagang keliling yang setiap hari harus menawarkan produk kain milik Prokura. Sudah empat tahun Gregor bekerja di perusahaan tekstil tempatnya dia bekerja sampai sekarang. Sebagai pegawai, Gregor tidak pernah absen dari pekerjaannya, seperti tampak pada kutipan berikut ini:

“... selama empat tahun ia bersama perusahaan, ia tak pernah sedikit pun sakit” (Kafka, 2000:5).

Setiap pagi, sebelum orang lain bangun, Gregor sudah harus bergegas pergi ke stasiun untuk bertemu dengan kurir perusahaan dan segera naik kereta paling awal agar tidak kesiangan bertemu dengan pelanggan. Dia juga sudah sampai di tempat para pelanggan dan harus menunggun pelanggan-pelanggan tersebut untuk menyelesaikan makan pagi mereka, sementara dia sendiri belum sempat makan pagi atau minum sesuatu. Keadaan itu dapat dilihat dari kutipan berikut ini:

“Tuhan”, pikirnya [Gregor]. "Pekerjaan apa yang sudah kupilih. Berkeliling dari hari ke hari. Lebih menyusahkan daripada pekerjaan di kantor. [...] „Tak ada yang lebih hina daripada selalu bangun lebih cepat. [...] Ketika aku ke hotel di pagi hari untuk pesanan-pesananku, kutemukan orang-orang ini masih sarapan pagi Aku harus melihat apa yang akan dikatakan bosku jika aku mencobanya; aku pasti dipecat dengan segera (Kafka, 2000:2-3)

Suatu pagi Gregor merasakan sakit di seluruh tubuhnya, dia tetap berusaha dengan keras untuk bangun dan berangkat kerja; namun apa daya, segala usahanya tidak memberikan hasil. Gregor tidak mampu menggerakkan tubuhnya. Dalam keadaan stress karena takut terlambat, tiba-tiba Gregor menyadari bahwa tubuhnya telah berubah menjadi kutu.

Ketika Gregor Samsa terbangun di suatu pagi [...], ia menemukan dirinya berubah di atas tempat tidur menjadi semacam kutu yang besar sekali.[...] Bagaimanapun keras ia mencoba mendorong dirinya dengan kasar ke samping, is selalu kembali ke belakang dengan sebuah gerakan bergoyang yang kecil. Ia mencoba seratus kali, [...] begitu menyakitkan, tak pernah berhenti.

(Kafka, 2000:2)

Gregor sadar bahwa dia harus tetap berangkat kerja karena kalau tidak berangkat pasti dia akan dipecat oleh majikannya. Para majikan tidak pernah percaya bahwa seseorang menderita sakit. Gregor tahu bahwa majikan akan beranggapan bahwa „,... tak ada orang sakit, yang ada hanyalah malas (Kafka, 2000:5). Apa yang dipikirkan Gregor ternyata benar. Ketika dia berusaha untuk bangun, dari luar kamar terdengar suara sang Prokura. Tanpa memperhatikan kerajinan dan kedisiplinan 
Gregor selama ini, sang Prokura marah-marah dan langsung mengancam akan memecat Gregor jika Gregor tidak segera keluar kamar dan menemui sang Prokura. Padahal kejadian itu baru beberapa menit dari waktu seharusnya Gregor bertemu kurir. Berikut ini pernyataan sang manajer: "Herr Samsa, ... pekerjaanmu tak lagi terjamin! Aku bermaksud mengatakannya secara pribadi, tetapi karena kau membuatku menghabiskan waktu sia-sia, aku tak melihat alasan untuk menjaga diri di depan orang tuamu“ (Kafka, 2000:17).

Keadaan Gregor semakin menyedihkan karena ketika dia berusaha berbicara dari dalam kamarnya, ternyata suaranya sudah berubah menjadi suara kutu. Ketika mencoba untuk berbicara, bahasanya tidak dipahami oleh sang Prokura yang ada di luar kamar maupun ayah, ibu, dan adiknya, Grete yang sudah bangun dan berusaha membujuk Gregor untuk keluar kamar.

Fragmen di atas menunjukkan metanarasi marxis yang menyatakan bahwa pergulatan utama dan pertama manusia adalah pergulatan untuk memenuhi kebutuhan materialnya (Faruk, 2014:26). Hubungan-hubungan sosial dibangun dalam proses produksi; Dan dalam lingkungan tersebut terdapat dua kelas sosial, yaitu kelas sosial yang menguasai alat produksi dan kelas sosial yang tidak menguasai alat produksi. Hubungan antar kelas dalam paham Marxis dicirikan dengan dua hal. Pertama, Kelas sosial yang berkuasa selalu berusaha mempertahankan kepentingannya. Kedua, dinamika sosial digerakkan oleh antagonisme antar kelas.

Fragmen ini menggambarkan paham Marxis seperti yang dinyatakan oleh Faruk di atas. Kelas sosial pertama diwakili oleh tokoh Prokura, sedangkan kelas sosial kedua diwakili oleh Gregor sang pedagang keliling. Hubungan di antara keduanya menunjukkan adanya dikotomi dan antagonisme, yaitu antara "Prokura" dan "pedagang keliling”. Kasus Gregor Samsa ini merupakan salah satu contoh terjadinya praktik kekuasaan otoriter di masyarakat dan ketidakadilan terhadap pihak yang lemah. Pihak yang kuat bertindak sewenangwenag terhadap pihak yang lemah.

Seharusnya secara hukum, Prokura dan memiliki hubungan yang harmonis dan saling membutuhkan. Setiap pegawai, termasuk pegawai rendahan semacam pedagang keliling secara hukum memiliki hak dan kewajiban yang melekat padanya. Kewajibannya antara lain, menunaikan tugas sesuai dengan tugas, pokok, dan fungsinya sebagai pedagang keliling. Dia tentu juga memiliki kewajiban, misalnya cuti, hak untuk tidak hadir dengan alasan kuat seperti sakit. Analisis di atas menunjukkan kesewenang-wenangan manajer terhadap bawahannya, pedagang keliling Gregor Samsa. Dalam fragmen ini pengertian pegawai terdistorsi menjadi semacam „budak“ yang hanya punya kewajiban tanpa hak, atau seperti „mesin“ yang tidak pernah „menderita“ sakit.

\section{Kesewenangwenangan dalam Keluarga}

Khairuddin (2008) menyatakan bahwa keluarga merupakan skala paling kecil dari semua organisasi formal yang merupakan 
struktur sosial. Dalam kebudayaan lama maupun modern keberadaan keluarga selalu ada dalam masyarakat. Keluarga, menurut Khairuddin lebih lanjut, dicirikan antara lain dengan adanya hubungan antar anggota yang dijiwai oleh kasih sayang dan rasa tanggung jawab; Para anggotanya memiliki tanggung jawab masing-masing. Dalam budaya patriakhat, laki-laki didorong untuk memiliki tanggung jawab lebih besar dari perempuan. Ayah merupakan pusat dalam keluarga; Sebagai kepala keluarga memiliki tanggung jawab paling besar dalam memelihara dan mendidik anak maupun dalam bidang ekonomi, keamanan, dan lain-lain. Seiring dengan perkembangan jaman, peranan dan fungsi anggota keluarga di era industri semakin bergeser. Meskipun demikian, peran dan fungsi ayah secara umum masih cukup besar.

Namun dalam novel Metamorfosa tanggung jawab ayah yang sangat besar dalam keluarga dimaknai secara salah. Makna tanggung jawab terdistorsi menjadi berkuasa. Dalam novel Metamorfosa diceritakan keluarga Samsa dengan anggotanya, yaitu pak Samsa sebagai ayah, bu Samsa sebagai ibu, Gregor anak lakilaki, dan Grete adik perempuan Gregor. Setelah usahanya bangkrut, keluarga Samsa mengalami masalah ekonomi. Pak Samsa merasa sudah tua dan tidak mau bekerja lagi karena merasa tidak kuat lagi untuk bekerja. Setiap hari kegiatannya hanya bersantai sambil minum kopi dan baca koran serta menonton televisi padahal dia memiliki hutang akibat kebangkrutannya. Bu Samsa yang dulu ikut menopang ekonomi keluarga dengan cara menerima jahitan, sudah lama harus meninggalkan kegiatan itu karena menderita sakit asma. Kegiatannya sehari-hari adalah mengurus rumah tangga dibantu seorang pembantu rumah tangga. Gregor, sebagai anak laki-laki satu-satunya dalam keluarga, terpaksa harus meninggalkan bangku sekolah untuk menggantikan ayahnya menafkahi keluarga dan membayar hutang-hutang pak Samsa.

Ketidakadilan dalam keluarga Samsa dialami oleh Gregor. Gregor yang seharusnya masih sekolah, terpaksa harus memikul tanggungjawab besar seorang kepala keluarga. Dia harus bekerja sangat keras membanting tulang dari pagi sampai malam untuk memenuhi kebutuhan keluarga. Dia juga berusaha dapat segera melunasi hutang-hutang ayahnya, dan bisa menabung untuk adiknya yang ingin sekolah musik. Tidak sedikit pun waktu yang punya untuk kegiatan pribadi. Sebaliknya, anggota keluarga yang lain tidak memiliki inisiatif untuk membantu meringankan beban Gregor; pak Samsa bahkan menyembunyikan tabungan dan suratsurat berharga miliknya.

Kesewenangwenangan pak Samsa terhadap Gregor tampak ketika Gregor berubah menjadi kutu. Di pagi hari, ketika Gregor tidak mampu bangun dari tempat tidurnya karena berubah menjadi kutu, pak Samsa langsung marah dan menggedor pintu kamar. Di balik pintu kamar Gregor, pak Samsa yang baru bangun berteriak-teriak: „Gregor, Gregor“ ia berteriak, „ada apa?“ Dan setelah beberapa saat, berkata lagi dengan nada mengingatkan, Gregor! Gregor!" (Kafka, 
2000:7). Pak Samsa tidak tahu bahwa sejak pagi, ketika anggota keluarga yang lain masih tidur nyenyak, Gregor sudah berusaha mati-matian untuk bangun dan berangkat bekerja. Yang ada dalam pikirannya hanyalah keluarga dan pekerjaan.

Ketika akhirnya Gregor mampu membuka pintu kamar, setelah mengalami jatuh berkali-kali dan luka-luka dimulutnya karena berusaha untuk memutar kunci pintu, yang diperolehnya justru penderitaan. Begitu melihat bentuk Gregor, pak Samsa bereaksi negatif: „Si ayah mengepalkan tinjunya dengan roman muka mengancam, seolah untuk memukul Gregor kembali ke kamarnya“ (Kafka, 2000:23-24). Pak Samsa semakin marah ketika melihat Gregor tidak kembali ke kamarnya dan membuka mulutnya, padahal waktu itu Gregor berusaha berbicara.

.. ayah Gregor - yang sampai sekarang tetap masih menjadi tuan bagi dirinya - [...] merebut dengan tangan kanannya tongkat jalan sang Prokura, yang tertinggal di belakang sebuah kursi dengan mantel dan topinya, mengambil dengan tangan kirinya sebuah surat kabar dari atas meja, dan mulai menyentakkan kakinya serta mengacungkan surat kabar dan tongkat untuk menggiring Gregor kembali ke dalam kamarnya. (Kafka, 2000:30).

Ancaman dan kemarahan sang ayah dan anggota keluarga lainnya selalu terjadi manakala Gregor ke luar dari kamar. Padahal kemunculannya selalu dengan maksud baik. Suatu malam Grete marah karena merasa terganggu dengan kehadiran Gregor dan ingin menyingkirkan Gregor dari rumah, dan disetujui oleh pak Samsa:

Aku [Grete] tak akan menyebut nama kakakku ketika aku bicara tentang monster ini di sini; aku hanya ingin berkata: kita harus mencari cara membuangnya. Kita telah melakukan semua yang mungkin secara manusiawi untuk memperhatikannya; aku percaya tak seorang pun dapat menyalahkannya kemudian.

„Ia seribu kali benar,“ kata si ayah.

(Kafka, 2000:92)

Penganiayaan terhadap Gregor selalu berulang manakala Gregor ke luar dari kamarnya, padahal Gregor ke luar kamar karena ingin menikmati permainan biola Grete. Suatu malam pak Samsa melempari Gregor dengan apel yang ada dihadapannya hingga Gregor terluka. Bahkan salah satu apel menancap di tubuh Gregor hingga mengeluarkan cairan semacam darah.

\section{Kesewenangwenangan dalam Lingkungan Sosial}

Fragmen berikutnya memperlihatkan kesewenangwenangan dalam lingkungan sosial yang dilakukan oleh manusia terhadap binatang Kesewenangwenangan diwakili oleh tokoh-tokoh Penyewa kamar dan tokoh Pembantu di rumah keluarga Samsa terhadap tokoh Gregor, yang sudah berubah menjadi kecoa. Orang- 
orang ini segera melakukan tindakan menyakiti Gregor, begitu mereka melihat Gregor; padahal Gregor tidak melakukan tindakan yang membahayakan atau menyakiti mereka.

Tindakan tokoh-tokoh Penyewa kamar dan Pembantu terhadap Gregor sang kecoa, secara eksplisit sudah tercermin pada judul. Kata "metamorfosa" didefinisikan sebagai proses perubahan bentuk dari tahap belum dewasa menjadi dewasa yang terjadi pada binatang, atau suatu proses perkembangan biologi pada hewan yang melibatkan perubahan penampilan fisik dan/atau struktur setelah kelahiran atau penetasan (Götz, 1997:650; Beicken, 2001:104). Perubahan fisik itu terjadi akibat pertumbuhan sel dan diferensiasi sel yang secara radikal berbeda. Dengan judul tersebut, pembaca yang memiliki pengetahuan tentang definisi kata metamorfosa akan mengarah penafsiran pertamanya pada kisah yang menceritakan tentang proses perubahan yang terjadi pada binatang belum dewasa menjadi dewasa.

Pandangan masyarakat manusia yang merendahkan binatang dan seringkali melakukan aniaya tanpa sebab-sebab yang jelas merupakan gambaran metanarasi universal yang diyakini oleh masyarakat sebagai hukum kebenaran. Namun, tampak bahwa hukum tersebut ternyata salah karena salah satu pihak, yaitu pihak yang lemah mengalami penderitaan. Sebaliknya, Gregor yang selalu mengalami penderitaan, justru merasa nyaman ketika diasingkan dalam kamarnya. Dia bisa melakukan apa saja yang ingin dia lakukan secara bebas.

Namun, di sini pembaca sudah dikejutkan oleh kalimat pertama yang menyatakan hal berbeda dari pengertian tentang kata metamorfosa. Perubahan bentuk tidak terjadi pada binatang melainkan pada manusia yang bernama Gregor Samsa menjadi binatang. Pada proses perubahan itu Gregor Samsa mengalami kebebasan setelah ke luar dari lingkungan manusia-manusia yang dipenuhi dengan kesewenangwenangan dan hidup sendiri dalam lingkungannya dan menyesuaikan diri dengan keberadaan dan lingkungannya

Dengan menggabungkan antara fiksi dan kenyataan, yaitu pada kejadian perubahan bentuk fisik manusia bernama Gregor menjadi binatang secara tiba-tiba seperti dalam dongeng atau mitos, novel Metamorfosa memiliki ciri sastra posmodern dengan ciri-ciri yang disebutkan oleh Derrida (2005:86), yaitu setiap teks memiliki logikanya sendiri dan harus dipahami dengan logika teks itu sendiri, dan ciri-ciri yang disebutkan oleh Ratna (2013:156) sebagai berikut: (1) fiksi posmodern ditandai dengan teknik "campur aduk", yaitu dua dunia yang tidak saling berhubungan, misalnya antara aspek-aspek tradisional dengan modern, kejadian nyata dan khayal, (2) fiksi posmodern menolak makna tunggal, menerima makna sementara, dunia seolah-olah kosong, dan akan diisi terus-menerus oleh pembaca, (3) karya yang mendorong pembaca untuk selalu bertanya-tanya mengenai eksistensi realitas yang sesungguhnya (4) kalau manusia (tokoh dalam sastra) dalam modernisme hidup dalam sistem, dalam posmodernisme, manusia dimungkinkan hidup secara 
SIMPULAN

lebih bebas, sebagai destruktur, (5) posmodernisme menolak manusia berkuasa, sebaliknya membela manusia tertindas.

Metanarasi dalam novel Metamorfosa memperlihatkan kesewenangwenangan atau dominasi pihak yang kuat terhadap pihak yang lemah. Kesewenangwenangan atau dominasi itu diperoleh dari tiga fragmen, yakni kesewenangwenangan dalam dunia kerja, kesewenangwenangan dalam keluarga, dan kesewenangwenangan dalam masyarakat.

Melalui fragmen-fragmen tersebut dapat dilihat penyimpangan yang dilakukan pihak-pihak yang kuat, sehingga timbul penderitaan, bahkan kehancuran yang berakhir dengan kematian bagi pihak yang lain. Tatanan hukum ketenagakerjaan, dan hukum keluarga, maupun dalam masyarakat terdistorsi oleh kesewenangwenangan pihak-pihak tertentu terhadap pihak lain yang lemah. Hasil analisis di atas memperlihatkan bahwa hukumhukum tertentu yang diuniversalkan mengakibatkan kontradiksikontradiksi, ketidakadilan, dan penderitaan. Fragmen-fragmen dalam novel Metamorfosa menunjukkan persamaan dengan posmodernisme, yakni membangun paradigma dengan tujuan mendekonstruksi segala bentuk dominasi, membawanya ke luar dari pusat-pusat yang telah ditentukan sebelumnya, sehingga melahirkan pluralisme.

\section{DAFTAR PUSTAKA}

Abidin, Zainal. 2002. Filsafat Manusia: Memahami Manusia melalui Filsafat. Bandung: PT Remaja Rosdakarya.

Beicken, Peter. 2001. Franz Kafka: Die Verwandlung. Stuttgart: Philipp Reclam.

Bertl, Klaus D. \& Müller, Ulrich. 1984. Vom Naturalismus zum Expressionismus Literatur des Kaiserreichs. Stuttgart: Klett.

Beutin, Wolfgang dkk.. 1984. Deutsche Literaturgeschichte von den Anfängen bis zur Gegenwart. Stuttgart: J.B. Metzlersche Verlagsbuchhandlung.

Cassirer, Ernst. 1987. Manusia dan Kebudayaan: Sebuah Esei tentang Manusia diterjemahkan dari An Essay on Man oleh Alois A. Nugroho. Jakarta: Gramedia.
Derrida, Jacques. 2005. Derrida diterjemahkan oleh Muhammad Al Fayyadl. Yogyakarta: PT LKiS Printing Cemerlang.

Faruk. 2014. Pengantar Sosiologi Sastra. Yogyakarta: Penerbit Pustaka Pelajar.

Forster, E. M.. 1971. Aspect of the Novel. Aylesbury, Bucks: Hazel Watson \&Viney Ltd.

Kafka, Franz. 2000. Metamorfosa diterjemahkan dari Metamorphosis oleh Eka Kurniawan. Yogyakarta: Yayasan Aksara Indonesia.

- 1953. Brief an den Vater. Frankfurt am Main: Fischer Taschenbuch Verlag.

Götz, Dieter; Haensch, Günther; Wellmann, Hans. 1997. Großwörterbuch Deutsch als Fremdsprache. Berlin und München: Langenscheidt KG. 
Khairuddin, H. 2008. Sosiologi Keluarga. Yogyakarta: Penerbit Liberty.

Lavine, T.Z. 2003. Filsafat Eksistensialisme Humanis diindonesiakan oleh Andi Iswanto dan Deddy Andrian Utama. Yogyakarta: Penerbit Jendela.

Lyotard, Jean-Frncois. 1988. The Differend:Phrases in Dispute diterjemahkan dari Le Differend oleh Georges Van Den Abbeele. Manchester: Manchester University Press.

Lyotard, Jean-Frncois . $1984 . \quad$ The Postmodern Condition: A Report on Knowlegde. Minneapolis: University of Minnesota Press.
Ratna, Nyoman Kutha. 2013. Teori, Metode, dan Teknik Penelitian Sastra. Yogyakarta: Pustaka Pelajar.

2010. Sastra dan Cultural Studies: Representasi Fiksi dan Fakta. Yogyakarta: Pustaka Pelajar.

Wellek, Rene dan Warren, Austin. 1993. Teori Kesusastraan diindonesiakan oleh Melani Budianta. Jakarta: PT Gramedia Pustaka Utama. 